\title{
Biobleaching application of cellulase poor and alkali stable xylanase from Bacillus pumilus SV-85S
}

\author{
Sushil Nagar • R. K. Jain • Vasanta Vadde Thakur • \\ Vijay Kumar Gupta
}

Received: 30 August 2012/ Accepted: 27 September 2012/Published online: 10 October 2012

(C) The Author(s) 2012. This article is published with open access at Springerlink.com

\begin{abstract}
The potential of extracellular alkali stable and thermo tolerant xylanase produced by Bacillus pumilus SV-85S through solid state fermentation was investigated in pulp bleaching in association with conventional bleaching using chlorine and chlorine dioxide. The biobleaching of kraft pulp with xylanase was the most effective at an enzyme dose of $10 \mathrm{IU} / \mathrm{g}$ oven dried pulp, $\mathrm{pH} 9.0$ and $120 \mathrm{~min}$ incubation at $55^{\circ} \mathrm{C}$. Under the optimized conditions, xylanase pretreatment reduced Kappa number by 1.6 points and increased brightness by 1.9 points. Subsequently, chlorine dioxide and alkaline bleaching sequences $\left(\mathrm{CDE}_{1} \mathrm{D}_{1} \mathrm{D}_{2}\right)$ finally resulted in brightness gain of 2.7 points as compared with the control. The pretreatment of pulp with xylanase resulted in $29.16 \%$ reduction in chlorine consumption by maintaining the same brightness as in control. An improvement in pulp strength properties was also observed after bleaching of xylanase pretreated pulp. Scanning electron microscopy revealed loosening and swelling of pulp fibers after enzyme treatment. These results clearly demonstrated that the B. pumilus SV-85S xylanase was effective as a pulp biobleaching agent. The decrease in chlorine consumption by pretreatment of pulp with xylanase apparently made the biobleaching process not only economical but also eco-friendly.
\end{abstract}

Keywords Xylanase - Biobleaching .

Bacillus pumilus . Solid state fermentation

S. Nagar · V. K. Gupta ( $₫)$

Department of Biochemistry, Kurukshetra University,

Kurukshetra 136119, India

e-mail: vkgupta59@ rediffmail.com

R. K. Jain · V. V. Thakur

Biotechnology and Lignin By-products, Central Pulp and Paper

Research Institute, Saharanpur 247001, India

\section{Introduction}

The secondary cell walls of plants contain a wide range of additional compounds that modify their mechanical properties and permeability. The wood is composed of cellulose (35-50\%), xylan (20-35\%), and lignin (10-25\%). Lignin is a complex phenolic polymer that penetrates the spaces in the cell wall between cellulose, hemicellulose, and pectin components, driving out water and strengthening the wall. Lignin is present in all woody plants and other agro-residues which are used as raw materials for paper manufacturing. The removal of lignin is essentially required during paper manufacturing. The brown color of the pulp is due to the presence of lignin which has to be removed during paper making process (Viikari et al. 1986; Koponen 1991).

The pulp and paper industry are modifying its pulping, bleaching, and effluent treatment technologies to reduce the environmental impact of mill effluents. Pre-bleaching of kraft pulp with xylanase minimizes the chlorine required for bleaching, which in turn reduces chloro-organic discharges (Koponen 1991; Viikari et al. 1994). The process of delignification of pulp using enzymes was first presented by Viikari et al. (1994). Xylanase (EC 3.2.1.8), a hydrolytic enzyme, is being used primarily for the removal of the lignin-carbohydrate complex that is generated in the kraft process and acts as physical barrier during chemical bleaching. For biobleaching, xylanase must be stable and active at both high temperature and alkaline conditions (Srinivasan and Rele 1999). Bacillus strains are particularly attractive producers of high levels of extracellular cellulase-free xylanases stable at both high temperature and alkaline pH (Battan et al. 2007; Dhiman et al. 2008; Gupta et al. 2008; Nagar et al. 2011).

In our laboratory, a novel xylanolytic bacterial strain viz. Bacillus pumilus SV-85S has been isolated from soil. It 
produces high levels of alkali stable and cellulase poor xylanase, of which production has been optimized under both submerged fermentation (Nagar et al. 2010) and solid state fermentation (Nagar et al. 2011). The aim of this study was to investigate the potential application of this alkali stable xylanase as a biobleaching agent in pulp and paper industry.

\section{Materials and methods}

Microbial strain and its growth conditions

Bacillus pumilus SV-85S (MTCC 9861), our own isolate, is being maintained on nutrient agar (in $\mathrm{g} / \mathrm{L}$ : peptone 5.0; beef extract 3.0 and agar 20.0) at $4{ }^{\circ} \mathrm{C}$ by transferring on to a fresh medium after every 4-6 weeks. The morphological, physiological, and biochemical characteristics of the isolated bacterial strain are already published (Nagar et al. 2010).

\section{Xylanase production and extraction}

The inoculum was prepared by inoculating the autoclaved (at $121{ }^{\circ} \mathrm{C}$ and $1.05 \mathrm{~kg} / \mathrm{cm}^{2}$ for $25 \mathrm{~min}$ ) nutrient broth containing $0.5 \%$ peptone and $0.3 \%$ beef extract with a loop full of the overnight grown culture of $B$. pumilus SV-85S followed by incubation at $37^{\circ} \mathrm{C}$ at $200 \mathrm{rpm}$. Xylanase was produced in Erlenmeyer flasks each containing $10 \mathrm{~g}$ of wheat bran and $30 \mathrm{~mL}$ mineral salt solution (in $\mathrm{g} / \mathrm{L}: \mathrm{MgSO}_{4} \cdot 7 \mathrm{H}_{2} \mathrm{O}, 0.5 ; \mathrm{K}_{2} \mathrm{HPO}_{4}, 1.5 ; \mathrm{pH}$ 8.0). The flasks were autoclaved at $121{ }^{\circ} \mathrm{C}\left(1.05 \mathrm{~kg} / \mathrm{cm}^{2}\right)$ for $25 \mathrm{~min}$, cooled, inoculated with $15 \%$ (v/w) of 18-h old inoculum and incubated at $30{ }^{\circ} \mathrm{C}$. The flasks were gently tapped intermittently to mix the contents. The contents of the flasks were harvested after $48 \mathrm{~h}$ of incubation. All the production experiments were conducted in triplicates and standard deviation (SD) was calculated to show the variability among the replicated flasks. The detailed optimized production of xylanase by $B$. pumilus SV-85S has already been reported (Nagar et al. 2011). Xylanase was extracted from the fermented carbon source with $100 \mathrm{~mL}$ of distilled water by squeezing through a muslin cloth followed by centrifugation at $10,000 \times g$ for $30 \mathrm{~min}$ at $4{ }^{\circ} \mathrm{C}$. The clear supernatant (crude extract) was used for enzyme assay and biobleaching studies.

\section{Enzyme assay}

The xylanase activity was assayed according to the method of Bailey et al. (1992) by measuring the amount of reducing sugars (xylose equivalent) liberated from xylan using 3,5-dinitrosalicylic acid (Miller 1959). The reaction mixture containing $490 \mu \mathrm{L}$ of $1 \%$ birch wood xylan
(Sigma) as substrate, and $10 \mu \mathrm{L}$ of appropriately diluted enzyme extract was incubated at $50{ }^{\circ} \mathrm{C}$ for $5 \mathrm{~min}$. The reaction was then terminated by adding $1.5 \mathrm{~mL}$ of 3,5-dinitrosalicylic acid reagent (in g/L: 3,5-dinitro-2hydroxybenzoic acid, 10.0; sodium potassium tartrate, 200.0; sodium hydroxide, 10.0; sodium sulfite, 0.5; phenol, 2.0). A control was run simultaneously that contained all the reagents, but the reaction was terminated prior to the addition of enzyme. The contents were placed in a boiling water bath for $10 \mathrm{~min}$ followed by cooling in ice-cold water. The absorbance of the resulting color was measured against the control at $540 \mathrm{~nm}$ in a spectrophotometer.

Cellulase activity (CMCase, i.e., carboxymethyl cellulase and FPase, i.e., filter paper digesting activity) was determined as described in Nagar et al. (2011). One unit (IU) of xylanase or cellulase activity was defined as the amount of enzyme that catalyzed the release of $1 \mu \mathrm{mol}$ of reducing sugar as xylose or glucose equivalent per minute under the specified assay conditions.

Biobleaching of kraft pulp $\left(\mathrm{E}_{0} \mathrm{CDE}_{1} \mathrm{D}_{1} \mathrm{D}_{2}\right)$

Xylanase produced by B. pumilus SV-85S under optimized submerged fermentation conditions was used for prebleaching of kraft pulp so as to evaluate its potential use as biobleaching agent.

The unbleached kraft pulp composed of different types of wood (eucalyptus, bamboo, poplar, eucalyptus rulla, vaneer, debarka bamboo hardwood, etc.) was cooked at $180{ }^{\circ} \mathrm{C}$ for $60 \mathrm{~min}$ at a pressure of $8.0-10.0 \mathrm{~kg} / \mathrm{m}^{3}$ and dried in an oven at $42-48 \pm 2{ }^{\circ} \mathrm{C}$ till a constant weight was attained. The consequential pulp was further used for biobleaching application. The optimum pretreatment conditions were decided by measuring Kappa number, reducing sugars, brightness, yellowness, and whiteness of the control, and enzyme-treated pulp samples. The experiment was laid down in completely randomized block design with different doses of the enzyme, temperature, retention time, and $\mathrm{pH}$ as individual treatments with three replications. The data were analyzed using Statistical Analysis Software (SAS) package and PROC GLM. The mean of different treatment effects were compared using least significant difference (LSD).

Enzyme pretreatment of kraft pulp $\left(\mathrm{E}_{0}\right)$

The oven dried pulp at $10 \%(\mathrm{w} / \mathrm{v})$ consistency was pretreated with $B$. pumilus SV-85S xylanase at a dose of $10 \mathrm{IU} / \mathrm{g}$ pulp in polyethylene bags under optimized conditions at $\mathrm{pH} 9.0$ and incubated at $55{ }^{\circ} \mathrm{C}$ for $120 \mathrm{~min}$ in a water bath. An untreated pulp sample (as control) was also incubated simultaneously under the identical conditions. The control and xylanase pretreated pulps were thoroughly 
washed and dewatered by a 75-mesh screen and then subjected to conventional chemical bleaching sequence $\left(\mathrm{CDE}_{1} \mathrm{D}_{1} \mathrm{D}_{2}\right)$. A part of the control and xylanase-treated pulps were used to prepare hand sheets according to Technical Association of Pulp and Paper Industry (TAPPI) standard methods so as to evaluate their brightness. The pulp samples were also analyzed for Kappa number.

Chlorine, chlorine dioxide treatment $(\mathrm{CD})$

The xylanase pretreated kraft pulp at $3 \%$ consistency was subjected to treatment with a mixture of chlorine:chlorine dioxide (in the ratio of 90:10) keeping total chlorine constant at $4.14 \%$ at $\mathrm{pH} 2.0$ for $1 \mathrm{~h}$ at $50{ }^{\circ} \mathrm{C}$. The pulp was then filtered and washed with distilled water. The resulting filtrate was analyzed to determine the amount of chlorine consumed. A part of the washed pulp was made into hand sheets to determine its brightness (according to TAPPI). The remaining pulp was used for the next bleaching step.

\section{Alkali treatment $\left(\mathrm{E}_{1}\right)$ step}

The washed kraft pulp (at $3 \%$ consistency) obtained after treatment with chlorine:chlorine dioxide was treated with sodium hydroxide $(2.5 \%)$ at $60{ }^{\circ} \mathrm{C}$ for $2 \mathrm{~h}$. The alkali was removed by thorough washing with distilled water. A part of the washed pulp was made into hand sheets to determine its brightness. The remaining pulp was used for the next bleaching step.

\section{Chlorine dioxide step $\left(\mathrm{D}_{1} \mathrm{D}_{2}\right)$}

The pulp (collected after alkali step) at $10 \%$ consistency was treated sequentially with 0.9 and $0.1 \%$ chlorine dioxide to remove traces of lignin at a temperature of $70{ }^{\circ} \mathrm{C}$. The pulp was filtered and washed to determine the amount of chlorine dioxide consumed during the treatment. The washed pulps were made into hand sheets to determine their brightness, yellowness, and whiteness. The strength properties such as tensile strength, breaking length, burst factor, burstness, tear factor, and tearness pulp of the hand sheets were also determined.

Analysis of pulp and paper properties

The hand sheets prepared from untreated and xylanasetreated pulps were evaluated for various physical properties following the TAPPI protocols (TAPPI Test Methods, Atlanta, GA, TAPPI Press, 1996). All the measurements were conducted in triplicate, with their averages and SD calculated. The Kappa number (a measure of lignin content), was determined by the treating the pulp samples with acidified potassium permanganate (TAPPI Protocol, T-236 om-85). The brightness ( $\mathrm{T} 452 \mathrm{om}-98$ ), yellowness, and whiteness of the hand sheets were measured at $457 \mathrm{~nm}$ with ISO Colourtech (USA). The strength properties viz. tensile strength (T 231 om-96), breaking length (T $404 \mathrm{~cm}$ 92), burstness, burst factor ( $\mathrm{T} 403 \mathrm{om}-97$ ), tear factor, and tearness ( $\mathrm{T} 414 \mathrm{om}-98$ ) were tested according to standard methods of TAPPI. The amount of total chlorine in the biobleached effluents was also determined to calculate the chlorine consumed during the bleaching process.

\section{Scanning electron microscopy (SEM)}

The surface of xylanase treated and an untreated kraft pulp sample was observed with SEM. The samples were dehydrated in an ascending grade of acetone, critical point dried (Critical point dryer, Polaron), and mounted on aluminium stubs. They were sputter coated (SCD 050 Super Cool Sputter System; Baltec Technology, Liechtenstein) with colloidal gold and observed under a Leo 435 VP scanning electron microscope (Cambridge, UK) at an operating voltage $15 \mathrm{kV}$. Images were digitally acquired by using a CCD camera attached to the microscope. The magnification for observing the loosening and swelling of pulp fibers was $350 \times$ and $1500 \times$, respectively.

\section{Results and discussion}

Application of xylanase in biobleaching of kraft pulp

Under optimized solid state fermentation conditions, B. pumilus SV-85S produced $73000 \mathrm{IU} / \mathrm{g}(\sim 7300 \mathrm{IU} / \mathrm{mL})$ of xylanase (Nagar et al. 2011). Further, cellulase activity was negligible (CMCase $0.017 \mathrm{IU} / \mathrm{g}$ and FPase $0.026 \mathrm{IU} / \mathrm{g}$ ) in the cell-free supernatant, indicating that xylanase was more or less cellulase free. The xylanase was found to be completely stable over a broad $\mathrm{pH}(5-11)$ range and retained $52 \%$ of its activity upon incubation at $70{ }^{\circ} \mathrm{C}$ for 30 min (Nagar et al. 2011). Its molecular weight was $23.7 \mathrm{kDa}$ which was lower as compared with several other xylanases. The molecular weight of this xylanase was determined by gel filtration chromatography through Sepharose 6B as well as by SDS-PAGE. These characteristics of $B$. pumilus SV-85S xylanase together with its economical production using wheat bran (a cost-effective substrate) suggested its potential implication as a biobleaching agent.

The application of $B$. pumilus SV-85S xylanase in biobleaching of kraft pulp was investigated according to $\mathrm{E}_{0} \mathrm{CDE}_{1} \mathrm{D}_{1} \mathrm{D}_{2}$ sequence in which the $\mathrm{E}_{0}$ stage refers to enzymatic pre-bleaching and $\mathrm{CDE}_{1} \mathrm{D}_{1} \mathrm{D}_{2}$ indicates conventional chemical bleaching. So, the pulp was pretreated with xylanase followed by bleaching with conventional 
chemical sequence $\mathrm{CDE}_{1} \mathrm{D}_{1} \mathrm{D}_{2}$. The role of xylanase in reducing chlorine consumption maintaining the same brightness as in control was also investigated. The use of xylanase in pre-bleaching has been given special attention as it may reduce the consumption of chlorine compounds by up to $30 \%$, so that a $15-20 \%$ reduction in organochlorines in the effluents could be achieved (Polizeli et al. 2005). The utilization of xylanases could lead to replacement of 5-7 $\mathrm{kg}$ chlorine dioxide per ton of kraft pulp and an average decrease of $2-4 \mathrm{U}$ in the Kappa number, a measure of lignin content in the cellulose pulp (Polizeli et al. 2005).

Enzymatic pretreatment of pulp $\left(\mathrm{E}_{0}\right)$

\section{Parametric optimization for pulp pretreatment with xylanase}

The process conditions viz. enzyme dose, incubation temperature, retention time, and $\mathrm{pH}$ were optimized for pre-bleaching of oven dried kraft pulp with xylanase so as to obtain effective dispersion of the enzyme. During optimization, various observations such as Kappa number, reducing sugars, brightness (\%ISO), yellowness, and whiteness were recorded. These parameters formed the basis for determining the efficiency of enzyme pretreatment. A decrease in Kappa number and increase in brightness would indicate a better efficiency of the enzyme treatment.

The effect of varying enzyme dose on the efficiency of pretreatment was investigated at $\mathrm{pH} 7.0$, temperature $50{ }^{\circ} \mathrm{C}$, and incubation time of $120 \mathrm{~min}$. The data in Table 1 revealed that the least mean Kappa number (18.3) was found at enzyme dose of $10 \mathrm{IU} / \mathrm{gds}$, followed by 12.5 and 15.0 IU/gds (18.4). The next higher value of Kappa number was at $7.5 \mathrm{IU} / \mathrm{gds}$ (18.5). However, all these values are statistically at par with each other. The maximum Kappa number was found in control. The measurement of brightness at different enzyme doses revealed that the brightness was maximum (36.7 \%ISO) in control and at the enzyme dose of $10 \mathrm{IU} / \mathrm{gds}$ followed by the values at 12.5 IU (36.5), 15 IU (36.4), and 7.5 IU (35.7). However, all these values of brightness at 7.5-15.0 IU/gds enzyme were statistically at par. The lowest brightness was found at $5.0 \mathrm{IU} / \mathrm{gds}$. Though statistically at par with $7.5 \mathrm{IU}, 10 \mathrm{IU} / \mathrm{gds}$ has been selected as the optimum enzyme dose for further experiments because of the lowest mean Kappa number and highest brightness at this dose. An enzyme dose of $10 \mathrm{IU} / \mathrm{g}$ pulp was found to be optimum for biobleaching of mixed hardwood kraft pulp by several researchers (Sindhu et al. 2006; Ahlawat et al. 2007; Dhiman et al. 2009; Sanghi et al. 2009; Garg et al. 2011). In contrast, maximum bleaching was reported with enzyme dose more than $10 \mathrm{IU} / \mathrm{g}$ (Kulkarni and Rao 1996; Bissoon et al. 2002; Khandeparkar and Bhosle 2007).

The effect of varying temperature on the efficiency of pretreatment was investigated at an enzyme dose $10 \mathrm{IU} / \mathrm{g}$, $\mathrm{pH} 7.0$, and incubation time $120 \mathrm{~min}$. A temperature of $55^{\circ} \mathrm{C}$ was found to be the most effective for pretreatment of kraft pulp by B. pumilus SV-85S xylanase as it resulted in the lowest Kappa number (Table 1). However, it was statistically at par with the Kappa number at 65 and $70{ }^{\circ} \mathrm{C}$. The maximum Kappa number was observed at $50{ }^{\circ} \mathrm{C}$. The measurement of brightness at different temperatures revealed that the brightness was maximum (36.7 \% ISO) at $60{ }^{\circ} \mathrm{C}$, which was statistically at par with that at 65 and $70{ }^{\circ} \mathrm{C}$. Changes in reducing sugars at different temperatures were statistically non-significant. Since Kappa number was the lowest at $55{ }^{\circ} \mathrm{C}$, this temperature was used for further experiments. Several researchers have reported optimum temperature in the range of $50-60{ }^{\circ} \mathrm{C}$ for pulp biobleaching (Beg et al. 2000; Sindhu et al. 2006; Battan et al. 2007; Dhiman et al. 2009; Garg et al. 2011).

The effect of varying retention time on the efficiency of pretreatment was investigated at an enzyme dose $10 \mathrm{IU} / \mathrm{g}$, $\mathrm{pH} 7.0$, and temperature $55^{\circ} \mathrm{C}$. The maximum efficiency of the enzyme in biobleaching was obtained after $120 \mathrm{~min}$ of incubation which caused reduction in mean Kappa number from 18.7 to 18.2 , though it was statistically nonsignificant as compared with the values at 0,60 , and $180 \mathrm{~min}$ (Table 1). The longer periods of incubation did not enhance the extent of biobleaching benefits significantly. So, in subsequent experiments, enzyme was incubated with the pulp for $120 \mathrm{~min}$. A similar incubation time $(2 \mathrm{~h})$ has been reported by various workers (Beg et al. 2000; Khandeparkar and Bhosle 2007; Sanghi et al. 2008; Ko et al. 2011). However, several researchers showed an optimum incubation time of $3 \mathrm{~h}$ (Garg et al. 1998; Bim and Franco 2000; Dhillon and Khanna 2000; Bissoon et al. 2002; Sindhu et al. 2006; Kiddinamoorthy et al. 2008).

The effect of $\mathrm{pH}$ on the efficiency of pretreatment was studied at an enzyme dose $10 \mathrm{IU} / \mathrm{g}$ pulp, retention time $120 \mathrm{~min}$, and temperature $50{ }^{\circ} \mathrm{C}$. The biobleaching efficiency of $B$. pumilus SV-85S xylanase was found to be the best at pH 9.0 as it showed the lowest Kappa number and maximum brightness (Table 1). At other $\mathrm{pH}$ values, Kappa number was higher and brightness was less than the values at $\mathrm{pH}$ 9.0. The release of reducing sugars was statistically non-significant at different $\mathrm{pH}$ values. The optimum working efficiency of xylanase used in this study at $\mathrm{pH} 9.0$ was in accordance with earlier reports (Garg et al. 2011; Kaur et al. 2011). However, the majority of cited work documented the optimum $\mathrm{pH}$ in the range of 6.0-8.0 (Chandralata et al. 2004; Sanghi et al. 2008; Manimaran et al. 2009; Ko et al. 2011).

The results on the optimization of enzymatic prebleaching revealed that bleaching was the most effective at 
Table 1 Parametric optimization for pretreatment of kraft pulp with xylanase by B. pumilus SV-85S

\begin{tabular}{|c|c|c|c|c|c|}
\hline Enzyme dose (IU/gds) & Kappa no. & Reducing sugars (g/50 g pulp) & Brightness \%ISO & Yellowness & Whiteness \\
\hline \multicolumn{6}{|c|}{ Optimization of enzyme dose } \\
\hline Control & $19.1^{\mathrm{c}}$ & $0.00^{\mathrm{b}}$ & $36.7^{\mathrm{a}}$ & $15.6^{\mathrm{b}}$ & -28.6 \\
\hline 5.0 & $18.8^{\mathrm{bc}}$ & $0.173^{\mathrm{a}}$ & $35.1^{\mathrm{b}}$ & $15.4^{\mathrm{ab}}$ & -27.9 \\
\hline 7.5 & $18.5^{\mathrm{ab}}$ & $0.180^{\mathrm{a}}$ & $35.7^{\mathrm{a}}$ & $15.3^{\mathrm{a}}$ & -27.8 \\
\hline 10.0 & $18.3^{\mathrm{a}}$ & $0.190^{\mathrm{a}}$ & $36.7^{\mathrm{a}}$ & $15.2^{\mathrm{a}}$ & -27.2 \\
\hline 12.5 & $18.4^{\mathrm{a}}$ & $0.188^{\mathrm{a}}$ & $36.5^{\mathrm{a}}$ & $15.2^{\mathrm{a}}$ & -27.0 \\
\hline 15.0 & $18.4^{\mathrm{a}}$ & $0.187^{\mathrm{a}}$ & $36.4^{\mathrm{a}}$ & $15.2^{\mathrm{a}}$ & -27.0 \\
\hline $\mathrm{CD}(p=0.05)$ & 0.28 & 0.07 & 0.95 & 0.27 & \\
\hline Temperature $\left({ }^{\circ} \mathrm{C}\right)$ & Kappa no. & Reducing sugars (g/50 g pulp) & Brightness \%ISO & Yellowness & Whiteness \\
\hline \multicolumn{6}{|c|}{ Optimization of treatment temperature } \\
\hline 50 & $18.3^{\mathrm{c}}$ & 0.190 & $36.1^{\mathrm{b}}$ & 15.2 & -27.2 \\
\hline 55 & $17.8^{\mathrm{a}}$ & 0.202 & $35.7^{\mathrm{c}}$ & 15.3 & -26.9 \\
\hline 60 & $18.1^{\mathrm{bc}}$ & 0.193 & $36.7^{\mathrm{a}}$ & 15.2 & -27.1 \\
\hline 65 & $18.0^{\mathrm{ab}}$ & 0.191 & $36.5^{\mathrm{a}}$ & 15.2 & -27.1 \\
\hline 70 & $18.0^{\mathrm{ab}}$ & 0.190 & $36.4^{\mathrm{ab}}$ & 15.2 & -27.0 \\
\hline $\mathrm{CD}(p=0.05)$ & 0.24 & NS & 0.32 & NS & \\
\hline Retention time (min) & Kappa no. & Reducing sugars (g/50 g pulp) & Brightness \%ISO & Yellowness & Whiteness \\
\hline \multicolumn{6}{|c|}{ Optimization of retention time } \\
\hline 0 & 18.7 & 0.185 & 36.0 & $15.8^{\mathrm{c}}$ & -27.3 \\
\hline 60 & 18.5 & 0.187 & 35.9 & $15.6^{\mathrm{b}}$ & -27.1 \\
\hline 120 & 18.1 & 0.190 & 36.1 & $15.2^{\mathrm{a}}$ & -27.1 \\
\hline 180 & 18.3 & 0.188 & 35.8 & $15.2^{\mathrm{a}}$ & -27.0 \\
\hline $\mathrm{CD}(p=0.05)$ & NS & NS & NS & 0.26 & \\
\hline $\mathrm{pH}$ & Kappa no. & Reducing sugars (g/50 g pulp) & Brightness \% ISO & Yellowness & Whiteness \\
\hline \multicolumn{6}{|l|}{ Optimization of $\mathrm{pH}$} \\
\hline 7 & $18.2^{\mathrm{c}}$ & 0.190 & $36.1^{\mathrm{b}}$ & 15.2 & -27.1 \\
\hline 8 & $18.1^{\mathrm{c}}$ & 0.196 & $36.4^{\mathrm{ab}}$ & 15.1 & -27.2 \\
\hline 9 & $17.1^{\mathrm{a}}$ & 0.216 & $36.7^{\mathrm{a}}$ & 14.8 & -27.1 \\
\hline 10 & $17.6^{\mathrm{b}}$ & 0.202 & $36.6^{\mathrm{a}}$ & 14.9 & -27.1 \\
\hline $\mathrm{CD}(p=0.05)$ & 0.20 & NS & 0.40 & NS & \\
\hline
\end{tabular}

In a column, different letters indicate statistically significant differences between the means $(p<0.05)$

All the experiments were performed with $10 \mathrm{IU}$ of xylanase at $\mathrm{pH} 7.0$, temperature $50{ }^{\circ} \mathrm{C}$, and incubation period of $120 \mathrm{~min}$, except the variable parameter

$C D$ critical difference, $N S$ not significant

an enzyme dose $10 \mathrm{IU} / \mathrm{g}$ pulp upon incubation for $2 \mathrm{~h}$ at $55^{\circ} \mathrm{C}$ and $\mathrm{pH} 9.0$.

\section{Pretreatment with xylanase under optimized conditions}

Pretreatment of pulp with xylanase $\left(E_{0}\right.$ stage $)$ under the above optimized conditions reduced the Kappa number by 1.6 points and increased the brightness from $36.9 \pm 0.12$ to $38.8 \pm 0.20 \%$ ISO (Table 2) indicating effectiveness of the enzyme in pulp bleaching. Several researchers have reported an increase in brightness and decline in Kappa number but with variable magnitude following the xylanase pretreatment (Jiang et al. 2006; Ahlawat et al. 2007; Sanghi et al. 2008; Garg et al. 2011). The increase in brightness after enzyme pretreatment might be due two reasons. First, the xylanase would act on the xylan precipitated on the lignin (Viikari et al. 1986). This xylan was precipitated due to lowering of the $\mathrm{pH}$ at the end of cooking stage. Its removal by the action of xylanase would enhance the accessibility of bleaching chemicals to the pulp fibers. The second reason was based on the ability of lignin to form complexes with polysaccharide such as xylan and 
some of the bonds being alkali-resistant might not have been hydrolyzed during the kraft process (Buchert et al. 1992). The xylanase acted by cleaving the remaining bonds between lignin and xylan, opening the structure of the cellulose pulp and leading to the fragmentation of xylan and subsequent extraction of the fragments (Paice et al. 1978). Treatment with xylanase rendered the pulp more permeable to subsequent chemical extraction of the residual brown lignin and lignin-carbohydrate from the fiber (Lei et al. 2008).

The results showed that xylanase may be employed as the first step for boosting pulp bleaching. The desirable properties of xylanase to be exploited for pulp bleaching include cellulase free/poor nature and active at both high temperature and alkaline $\mathrm{pH}$. The cellulase free/poor nature of xylanase would preserve the cellulose fibers. All these characteristics are fulfilled by $B$. pumilus SV-85S xylanase used in this study for pulp bleaching (Nagar et al. 2010, 2011). Moreover, xylanase in crude form could be employed for pulp bleaching.

\section{Chemical bleaching $\left(C D E_{1} D_{1} D_{2}\right)$}

The xylanase pretreated pulp when subjected to $C \mathrm{DE}_{1} \mathrm{D}_{1} \mathrm{D}_{2}$ bleaching sequence resulted in notable increase in brightness as compared with control after each stage of processing (Table 2). The enhancement in brightness in both the pulp samples was highest at $\mathrm{D}_{1}$ stage. The final gain in brightness of enzyme pretreated pulp (83.9\%ISO) was 2.7 points as compared with the control (81.2\%ISO) demonstrating

Table 2 Effect of B. pumilus SV-85S xylanase treatment on chlorine consumption

\begin{tabular}{|c|c|c|c|c|c|c|}
\hline \multirow[t]{2}{*}{ Parameters } & \multirow[t]{2}{*}{ Control $\left(\mathrm{CDE}_{1} \mathrm{D}_{1} \mathrm{D}_{2}\right)$} & \multicolumn{5}{|c|}{ Enzyme treated $\left(\mathrm{E}_{0} \mathrm{CDE}_{1} \mathrm{D}_{1} \mathrm{D}_{2}\right)$} \\
\hline & & $100 \%$ & $90 \%$ & $80 \%$ & $70 \%$ & $60 \%$ \\
\hline \multicolumn{7}{|c|}{ Enzyme treatment stage $\left(\mathrm{E}_{0}\right)$} \\
\hline Pulp consistency (\%) & 10 & 10 & & & & \\
\hline Enzyme dose (U/g) & Nil & 10 & & & & \\
\hline Temperature $\left({ }^{\circ} \mathrm{C}\right)$ & 55 & 55 & & & & \\
\hline Retention time (min) & 120 & 120 & & & & \\
\hline $\mathrm{pH}$ & 9.0 & 9.0 & & & & \\
\hline Kappa no. & $18.8 \pm 0.17$ & $17.2 \pm 0.28$ & & & & \\
\hline Brightness ISO (\%) & $36.9 \pm 0.12$ & $38.8 \pm 0.20$ & & & & \\
\hline \multicolumn{7}{|c|}{$\mathrm{Cl}_{2}-\mathrm{ClO}_{2}$ treatment Stage $(\mathrm{CD})$} \\
\hline $\mathrm{Cl}_{2}$ added $(\%)$ & 4.14 & 4.14 & 3.73 & 3.31 & 2.90 & 2.48 \\
\hline $\mathrm{Cl}_{2}$ consumed $(\%)$ & 4.08 & 3.91 & 3.46 & 3.23 & 2.86 & 2.41 \\
\hline Brightness ISO (\%) & $52.2 \pm 2.32$ & $56.9 \pm 0.16$ & $55.6 \pm 1.09$ & $55.5 \pm 2.18$ & $55.5 \pm 1.22$ & $53.5 \pm 1.22$ \\
\hline \multicolumn{7}{|c|}{ Alkali treatment stage $\left(\mathrm{E}_{1}\right)$} \\
\hline Alkali added (\%) & 2.5 & 2.5 & 2.5 & 2.5 & 2.5 & 2.5 \\
\hline $\mathrm{H}_{2} \mathrm{O}_{2}$ added $(\%)$ & 1.0 & 1.0 & 1.0 & 1.0 & 1.0 & 1.0 \\
\hline Brightness ISO (\%) & $57.2 \pm 3.12$ & $62.9 \pm 1.12$ & $61.6 \pm 2.17$ & $61.7 \pm 0.11$ & $61.8 \pm 1.70$ & $57.8 \pm 2.20$ \\
\hline \multicolumn{7}{|l|}{$\mathrm{ClO}_{2}$ treatment stage $\left(\mathrm{D}_{1}\right)$} \\
\hline $\mathrm{ClO}_{2}$ added $(\%)$ & 0.80 & 0.80 & 0.72 & 0.64 & 0.56 & 0.48 \\
\hline $\mathrm{ClO}_{2}$ consumed $(\%)$ & 0.72 & 0.7 & 0.69 & 0.62 & 0.54 & 0.46 \\
\hline Brightness ISO (\%) & $78.9 \pm 22.2$ & $81.9 \pm 25.12$ & $80.1 \pm 13.07$ & $79.7 \pm 18.21$ & $78.2 \pm 11.20$ & $77.1 \pm 13.0$ \\
\hline \multicolumn{7}{|c|}{$\mathrm{ClO}_{2}$ treatment stage $\left(\mathrm{D}_{2}\right)$} \\
\hline $\mathrm{ClO}_{2}$ added $(\%)$ & 0.1 & 0.1 & 0.09 & 0.08 & 0.07 & 0.06 \\
\hline $\mathrm{ClO}_{2}$ consumed $(\%)$ & 0.07 & 0.07 & 0.06 & 0.06 & 0.05 & 0.06 \\
\hline Brightness ISO (\%) & $81.2 \pm 2.32$ & $83.6 \pm 1.37$ & $82.4 \pm 2.17$ & $82.3 \pm 1.91$ & $81.3 \pm 0.62$ & $78.8 \pm 1.42$ \\
\hline Yellowness & $1.71 \pm 0.17$ & $1.41 \pm 0.18$ & $1.48 \pm 0.29$ & $1.53 \pm 0.80$ & $1.89 \pm 0.22$ & $2.02 \pm 0.19$ \\
\hline Whiteness & $78.0 \pm 1.37$ & $80.0 \pm 2.18$ & $82.4 \pm 3.29$ & $82.3 \pm 2.90$ & $80.1 \pm 4.21$ & $77.1 \pm 3.42$ \\
\hline \multicolumn{7}{|l|}{ Comparative results } \\
\hline Total chlorine used & 4.87 & 4.68 & 4.21 & 3.91 & 3.45 & 2.93 \\
\hline Chlorine saved (\%) & 0.00 & 3.90 & 13.55 & 19.71 & 29.16 & 39.84 \\
\hline Brightness ISO (\%) & 81.2 & 83.9 & 86.6 & 85.7 & 81.8 & 78.2 \\
\hline Unit improved (\%) & 0.00 & 2.96 & 1.48 & 1.35 & 0.12 & -2.95 \\
\hline
\end{tabular}


Table 3 Effect of B. pumilus SV-85S xylanase treatment on properties of bleached pulp

\begin{tabular}{lccc}
\hline Pulp properties & \multicolumn{1}{c}{ Control } & Enzyme treated & Gain (\%) \\
\hline Tensile strength (N) & $57.3 \pm 1.56$ & $67.2 \pm 2.96$ & 17.28 \\
Breaking length (m) & $6830 \pm 8.23$ & $7413 \pm 9.34$ & 8.69 \\
Burst factor & $38.1 \pm 1.18$ & $40.9 \pm 1.28$ & 7.34 \\
Burstness (lb/in. ${ }^{2}$ ) & $43.24 \pm 4.56$ & $45.88 \pm 5.66$ & 6.10 \\
Tear Factor & $61.6 \pm 2.31$ & $68.0 \pm 3.87$ & 10.38 \\
Tearness (mN) & $192 \pm 12.34$ & $210 \pm 13.45$ & 10.52 \\
\hline
\end{tabular}

efficacy of the enzymatic pre-bleaching. Li et al. (2005) reported that pretreatment with cellulase-free xylanase isolated from the fungus Thermomyces lanuginosus brightened the pulp by $1.8 \%$ ISO over the control.

To evaluate the potential of xylanase from $B$. pumilus SV-85S in reducing the chlorine consumption, chemical bleaching of enzyme pretreated pulp was carried out by successively reducing the amount of chlorine to obtain the same brightness as in the control. It was evident from the data shown in Table 2 that pretreatment with the B. pumilus SV-85S xylanase finally resulted in $29.16 \%$ reduction in chlorine consumption by maintaining the same brightness level as in control. The decrease in chlorine consumption by the pretreatment of pulp with xylanase apparently made the biobleaching process not only economical but also eco-friendly. These results clearly showed that the B. pumilus SV-85S xylanase was effective as pulp biobleaching agent and it was more efficient as compared to several other xylanases reported earlier. Enzymatic biobleaching with xylanase from B. pumilus ASH resulted in $20 \%$ reduction in chlorine consumption without any change in brightness (Battan et al. 2007). Xylanase from B. stearothermophilus SDX reduced the chlorine consumption up to $15 \%$ while its combination with pectinase resulted in $20 \%$ reduction (Dhiman et al. 2008). Treatment of eucalyptus pulp with commercial xylanases such as Novozyme 473, and Cartazyme HS-10 reduced the chlorine consumption by $31 \%$ and increased the final brightness by 2.1-4.9 points (Bajpai et al. 1994). Xylanase P (a commercial enzyme) improved the brightness of kraft pulp by 5.6 points when used at $10 \mathrm{U} / \mathrm{g}$ of moisture free pulp and caused $10 \%$ reduction in chlorine consumption (Madlala et al. 2001). The greater bleaching potential of B. pumilus $\mathrm{SV}-85 \mathrm{~S}$ xylanase used in the present investigation might be due to its lower molecular mass, stability at alkaline $\mathrm{pH}$ and higher temperatures and negligible cellulase activity.

\section{Effect of xylanase treatment on paper quality}

The pulp subjected to $\mathrm{E}_{0} \mathrm{CDE}_{1} \mathrm{D}_{1} \mathrm{D}_{2}$ bleaching sequence showed improvement in its physical properties as compared with the control. The data given in Table 3 revealed a gain in various strength properties such as tensile strength, breaking length, burst factor, burst, tear factor, and tearness in handmade paper sheets of enzyme-treated pulp compared wih untreated pulp. Thus, enzyme treatment resulted in an improvement in the quality of paper. The favorable effect of xylanase treatment of paper strength properties of pulp has been documented by various workers (Ninawe et al. 2006; Battan et al. 2007; Garg et al. 2011; Kaur et al. 2011; Ko et al. 2011). Dhiman et al. (2008) reported significant improvement in various physical properties through single and mixed lay out strategy. Beg et al. (2000) also recorded an improvement in tensile strength and burst factor by up to 63 and $8 \%$, respectively, by xylanase produced from Streptomyces sp. QG-11-3. Xylanase from Staphylococcus sp. SG-13 has been shown to increase the tensile strength and burst factor by 10 and $17 \%$ respectively (Gupta et al. 2000).

\section{SEM of xylanase-treated pulp}

SEM studies clearly showed morphological changes in the pulp fibers after treatment with crude xylanase. A comparison of SEM images from the control and SV-85S xylanase-treated samples revealed an increase in loosening and swelling of pulp fibers after treatment with the enzyme (Fig. 1). The surface of untreated pulp fibers appeared smooth, whereas that of the treated fibers was rough. These changes in pulp fibers resulted in its refining facilitating enhanced accessibility of chemicals used in subsequent bleaching stages. The fiber swelling also improved physical properties of the pulp. Similar disruption and separation of pulp fibers upon enzyme treatment by SEM was reported earlier (Poorna and Prema 2007; Sanghi et al. 2009).

\section{Conclusion}

Exploiting xylanase for pre-bleaching has been given special attention in view of the environmental regulations that have restricted the use of chlorine compounds in bleaching processes in the paper and cellulose industries. The present investigation revealed that enzymatic pretreatment of pulp with cellulase-free, thermo tolerant, and alkali stable xylanase produced by $B$. pumilus SV-85S 


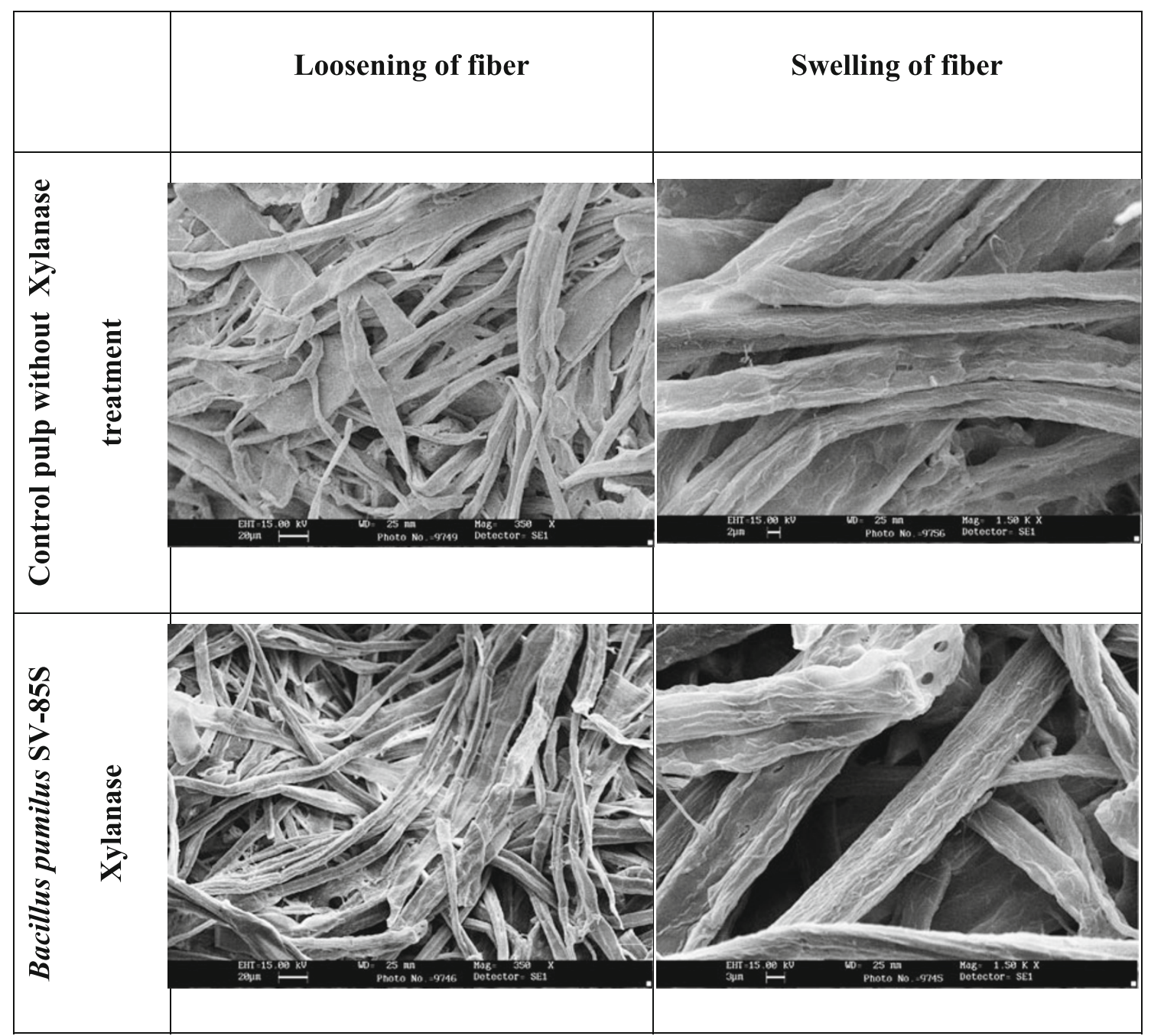

Fig. 1 SEM micrographs of untreated and xylanase-treated paper pulp showing loosening and swelling of fibers

reduced the chlorine consumption by $29.16 \%$ with the same brightness level as in control. This enzyme is apparently superior to the most other available xylanases, which have been shown to reduce chlorine consumption up to $20 \%$. Pre-bleaching with xylanase also led to improvement in various pulp strength properties like tensile strength, breaking length, burst factor, burstness, tear factor, and tearness. The above characteristics of B. pumilus SV-85S enzyme together with its economical production using cost-effective and abundantly available wheat bran in high levels would facilitate its exploitation as biobleaching agent in pulp and paper industry leading to substantial reduction in chlorine consumption thereby minimizing the risk of environmental pollution.

Acknowledgments Mr. Sushil Nagar greatly acknowledges the financial assistance received from University Grants Commission, India as Senior Research Fellowship under Rajiv Gandhi National Fellowship Scheme. We also acknowledge the help received from Electron Microscope Facility (SAIF), All India Institute of Medical
Sciences, New Delhi for SEM studies. The authors are thankful to Dr. R. Malhotra, Scientist (Statistics), National Dairy Research Institute (NDRI), Karnal for his help in statistical analysis of the data.

Open Access This article is distributed under the terms of the Creative Commons Attribution License which permits any use, distribution, and reproduction in any medium, provided the original author(s) and the source are credited.

\section{References}

Ahlawat S, Battan B, Dhiman SS, Sharma J, Mandhan RP (2007) Production of thermostable pectinase and xylanase for their potential application in bleaching of kraft pulp. J Ind Microbiol Biotechnol 34:763-770

Bailey MJ, Biely P, Poutanen K (1992) Laboratory testing of method for assay of xylanase activity. J Biotechnol 23:257-270

Bajpai P, Bhardwaj NK, Bajpai PK, Jauhari MB (1994) The impact of xylanases on bleaching of eucalyptus kraft pulp. J Biotechnol $38: 1-6$

Battan B, Sharma J, Dhiman SS, Kuhad RC (2007) Enhanced production of cellulase-free thermostable by Bacillus pumilus 
ASH and its potential application in paper industry. Enzyme Microb Technol 41:733-739

Beg QK, Bhushan B, Kapoor M, Hoondal GS (2000) Enhanced production of a thermostable xylanase from Streptomyces sp. QG-11-3 and its application in biobleaching of eucalyptus kraft pulp. Enzyme Microb Technol 27:459-466

Bim A, Franco T (2000) Extraction in aqueous two phase systems of alkaline xylanase produced by Bacillus pumilus and its application in kraft pulp bleaching. J Chromatogr 743:349-356

Bissoon S, Christov L, Singh S (2002) Bleach-enhancing effects of purified xylanase from Thermomyces lanuginosus SSBP on bagasse pulp. Proc Biochem 38:71-577

Buchert J, Ranua M, Kantelinen A, Viikari L (1992) The role of two Trichoderma reesei xylanases in the bleaching of pine kraft pulp. Appl Microbiol Biotechnol 37:825-829

Chandralata R, Muraleedharan U, Gaud VR, Mishra R (2004) Xylanases of marine fungi of potential use for biobleaching of paper pulp. J Ind Microbiol Biotechnol 31:433-441

Dhillon A, Khanna S (2000) Production of a thermostable alkalitolerant xylanase from Bacillus circulans $\mathrm{AB} 16$ grown on wheat straw. World J Microbiol Biotechnol 16:325-327

Dhiman SS, Sharma J, Battan B (2008) Industrial applications and future prospects of microbial xylanases: a review. Bioresources 3:1377-1402

Dhiman SS, Garg G, Mahajan R, Garg N, Sharma J (2009) Single lay out and mixed lay out enzymatic processes for biobleaching of kraft pulp. Bioresour Technol 100:4736-4741

Garg AP, Roberts JC, McCarthy AJ (1998) Bleach boosting effect of cellulase-free xylanase of Streptomyces thermoviolaceus and its comparison with two commercial enzyme preparations on birchwood kraft pulp. Enzyme Microb Technol 22:594-598

Garg G, Mahajan R, Kaur A, Sharma J (2011) Xylanase production using agro-residue in solid-state fermentation from Bacillus pumilus ASH for biodelignification of wheat straw pulp. Biodegradation 22:1143-1154

Gupta S, Bhushan B, Hoondal GS (2000) Isolation, purification and characterization of xylanase from Staphylococcus sp. SG-13 and its application in biobleaching of kraft pulp. J Appl Microbiol 88:325-333

Gupta S, Kapoor M, Sharma KK, Nair LM, Kuhad RC (2008) Production and recovery of an alkaline exo-polygalacturonase from Bacillus subtilis RCK under solid state fermentation using statistical approach. Bioresour Technol 99:937-945

Jiang ZQ, Li XT, Yang SQ, Li LT, Li Y, Feng WY (2006) Biobleach boosting effect of recombinant xylanase $\mathrm{B}$ from the hyperthermophilic Thermotoga maritima on wheat straw pulp. Appl Microbiol Biotechnol 70:65-71

Kaur A, Mahajan R, Singh A, Garg G, Sharma J (2011) Application of cellulase free xylano-pectinolytic enzymes from the same bacterial isolate in biobleaching of kraft pulp. Bioresour Technol 101:9150-9155

Khandeparkar R, Bhosle NB (2007) Application of thermoalkalophilic xylanase from Arthrobacter sp. MTCC 5214 in biobleaching of kraft pulp. Bioresour Technol 98:897-903

Kiddinamoorthy J, Anceno AJ, Haki GD, Rakshit SK (2008) Production, purification and characterization of Bacillus sp. GRE7 xylanase and its application in eucalyptus kraft pulp biobleaching. World J Microbiol Biotechnol 24:605-612

Ko CH, Tsai CH, Tu J, Yang BY, Hsieh DL, Jane WN, Shih TL (2011) Identification of Paenibacillus sp. 2S-6 and application of its xylanase on biobleaching. Int Biodeter Biodegr 65:334-339

Koponen R (1991) Enzyme systems prove their potential. Pulp pap Int $33: 81-83$
Kulkarni N, Rao M (1996) Application of xylanase from alkalophilic thermophilic Bacillus sp. NCIM 59 in biobleaching of bagasse pulp. J Biotechnol 51:167-173

Lei X, Lin L, Li K (2008) Effect of xylanase pretreatment on wood chips on fiber separation in the CTMB refining process. BioResources 3:801-815

Li XT, Jiang ZQ, Li LT, Yang SQ, Feng WY, Fan JY, Kusakabe I (2005) Characterization of a cellulase-free, natural xylanase from Thermomyces lanuginosus CBS and its biobleaching effect on wheat straw pulp. Enzyme Microbiol Biotechnol 96: $1370-1379$

Madlala AM, Bissoon S, Singh S, Christov L (2001) Xylanaseinduced reduction of chlorine dioxide consumption during elemental chlorine-free bleaching of different pulp types. Biotechnol Lett 23:345-351

Manimaran A, Santhosh KK, Permaul K, Singh S (2009) Hyper production of cellulase-free xylanase by Thermomyces lanuginosus SSBP on bagasse pulp and its application in biobleaching. Appl Microbiol Biotechnol 81:887-893

Miller GL (1959) Use of dinitrosalicylic acid reagent for determination of reducing sugar. Anal Chem 31:426-428

Nagar S, Gupta VK, Kumar D, Kumar L, Kuhad RC (2010) Production and optimization of cellulase free alkali stable xylanase by Bacillus pumilus SV-85S in submerged fermentation. J Ind Microbiol Biotechnol 37:71-83

Nagar S, Mittal A, Kumar D, Kumar L, Gupta VK (2011) Hyper production of alkali stable xylanase in lesser duration by Bacillus pumilus SV-85S using wheat bran under solid state fermentation. New Biotechnol 28:581-587

Ninawe S, Lal R, Kuhad RC (2006) Isolation of three xylanaseproducing strains of actinomycetes and their identification using molecular methods. Curr Microbiol 53:178-182

Paice MG, Jurasek L, Carpenter MR, Smillie LB (1978) Production, characterization and partial amino acid sequence of xylanase from Schizophyllum commune. Appl Environ Microbiol 36: 802-808

Polizeli MLTM, Rizzatti ACS, Monti R, Terenzi HF, Jorge JA, Amori DS (2005) Xylanases from fungi: properties and industrial applications. Appl Microbiol Biotechnol 67:577-591

Poorna CA, Prema P (2007) Production of cellulase free endoxylanase from novel alkalophilic thermotolerant Bacillus pumilus by solid state fermentation and its application in wastepaper recycling. Bioresour Technol 98:485-490

Sanghi A, Garg N, Sharma J, Kuhar K, Kuhad RC, Gupta VK (2008) Optimization of Xylanase Production using inexpensive agroresidue by alkalophilic Bacillus subtilis ASH in solid-state fermentation. World J Microbiol Biotechnol 24:633-640

Sanghi A, Garg N, Kuhar K, Kuhad RC, Gupta VK (2009) Enhanced production of cellulase-free xylanase by alkalophilic Bacillus subtilis ASH and its application in biobleaching of kraft pulp. BioResources 4:1109-1129

Sindhu I, Chhibber S, Caplash N, Sharma P (2006) Production of cellulase free xylanase from Bacillus megaterium by solid state fermentation for biobleaching of pulp. Curr Microbiol 53:167-172

Srinivasan MC, Rele MV (1999) Microbial xylanases for paper industry. Curr Sci 77:137-142

Viikari L, Ranuae M, Kantelinen A, Linko M, Sundquist J (1986) Application of enzymes in bleaching. Proceedings of the 3rd international conference on biotechnology in the pulp and paper industry, Stockholim, pp 67-69

Viikari L, Kantelinen A, Sundquist J, Linko M (1994) Xylanase in bleaching: from an idea to the industry. FEMS Microbiol Rev $13: 335-350$ 